\title{
Survival of rat embryos after freezing
}

\author{
M. Kasai, K. Niwa and A. Iritani \\ Department of Animal Science, College of Agriculture, Kyoto University, Kyoto 606, Japan
}

\begin{abstract}
Summary. The effects of cryoprotectants and freeze-thawing procedures on the survival of frozen rat morulae were examined. In the samples frozen and thawed in the presence of DMSO, ethylene glycol or glycerol, higher proportions of the embryos developed into blastocysts in culture when they were frozen slowly $(50-71 \%)$ than when they were frozen rapidly $(20-39 \%)$, but the thawing rates of the slowly frozen samples did not affect the viability of the embryos. When erythritol was used as a cryoprotectant, all of the embryos frozen-thawed slowly were killed but rapidly thawed embryos survived regardless of the freezing rate (36-52\%). The morulae frozen slowly with ethylene glycol or glycerol and those frozen rapidly with DMSO or erythritol were transferred to recipients after thawing and full-term young were obtained with all 4 cryoprotectants.
\end{abstract}

\section{Introduction}

We have reported that the effectiveness of freeze-thawing procedures for mouse embryos varies according to the cryoprotective agents used (Kasai, Niwa \& Iritani, 1981). This study examines such effects with rat morulae.

\section{Materials and Methods}

Embryos were obtained from naturally mated female rats (4-8 months old) of the Wistar strain. The day on which spermatozoa were found in the vagina was taken as Day 1 of pregnancy. Morulae were flushed from the uterine horns with a modified Dulbecco's phosphate-buffered saline (PBS: Whittingham, 1971) on the evening of Day 4 of pregnancy. They were washed once with fresh PBS and 4-30 embryos were pipetted into $0.2 \mathrm{ml}$ PBS containing DMSO, ethylene glycol, glycerol or erythritol in a glass test-tube $(10 \times 100 \mathrm{~mm})$ pre-cooled in an ice bath. The concentration of cryoprotectants was $1.5 \mathrm{M}$ for slow freezing and $2.0 \mathrm{M}$ for rapid freezing. Samples were cooled and warmed using the procedures reported previously for mouse embryos (Kasai et al., 1980, 1981). Briefly, after equilibration for 5-15 $\mathrm{min}$ in the ice bath, tubes were transferred into an ethanol bath at $-4(1.5 \mathrm{M})$ or $-7^{\circ} \mathrm{C}(2.0 \mathrm{M})$ and seeded. Tubes were then either (a) cooled slowly to $-50^{\circ} \mathrm{C}$ at $0.33^{\circ} \mathrm{C} / \mathrm{min}$ and to $-75^{\circ} \mathrm{C}$ at $1{ }^{\circ} \mathrm{C} / \mathrm{min}$, and then plunged into liquid nitrogen, or (b) cooled rapidly by transfer into $-20^{\circ} \mathrm{C}$ alcohol for $10 \mathrm{~min}$, suspended in $\sim-100^{\circ} \mathrm{C}$ nitrogen vapour for $10 \mathrm{~min}$, and then plunged into liquid nitrogen. After storage for $30-626$ days, samples were thawed slowly in room temperature air or rapidly by agitation in $30-35^{\circ} \mathrm{C}$ water. Cryoprotectants were removed by sucrose dilution (procedure $\mathrm{C}$ of Kasai et al., 1980). Briefly, embryos were transferred into $\sim 20^{\circ} \mathrm{C}$ solution of PBS plus the 
cryoprotectant and $0.5 \mathrm{M}$-sucrose for 1-2 min, followed by $0.5 \mathrm{M}$-sucrose in PBS for 2-5 min, and finally fresh PBS.

The survival of the frozen and thawed morulae was ascertained by 24 -h culture in $0.4 \mathrm{ml}$ modified Krebs-Ringer-bicarbonate solution (Toyoda \& Chang, 1974) in a plastic culture dish under paraffin oil, in $5 \% \mathrm{CO}_{2}$ in air at $37^{\circ} \mathrm{C}$. Embryos were scored as viable if they formed a blastocoele larger than the cell mass. Experiments were replicated 4-6 times for each treatment.

Further development of the embryos was examined after removal of the cryoprotectant by transfer of 3-7 morphologically normal morulae into the anterior portion of each uterine horn of recipients (Wistar strain) on Day 4 of pseudopregnancy, induced by mating with a vasectomized and proven sterile Wistar male. The recipients were allowed to litter.

\section{Results}

The ability of frozen-thawed rat morulae to develop into blastocysts was affected by the cryoprotectant and the freeze-thawing procedure (Table 1). Higher survival rates were obtained for DMSO, ethylene glycol or glycerol when the embryos were frozen slowly (50-71\%) than when they were frozen rapidly $(20-39 \%)$. However, the thawing rate of the slowly frozen embryos did not affect their viability. All the embryos frozen-thawed slowly in erythritol were killed, but rapidly thawed embryos survived regardless of the freezing rate (36-52\%).

As shown in Table 2, normal young were obtained from the embryos frozen and thawed in the presence of all the cryoprotectants. Normal young (16 males, 9 females) were born on Day $22-24$ to 8 recipients that had received a total of 87 embryos. The 21 young surviving after 21 days appeared to grow normally.

Table 1. Effects of various cryoprotectants and freeze-thawing procedures on in-vitro development of rat morulae after storage at $-196^{\circ} \mathrm{C}$

\begin{tabular}{|c|c|c|c|c|c|c|}
\hline $\begin{array}{l}\text { Freezing } \\
\text { rates }\end{array}$ & $\begin{array}{l}\text { Thawing } \\
\text { rates } \\
\left({ }^{\circ} \mathrm{C} / \mathrm{min}\right)\end{array}$ & Cryoprotectant* & $\begin{array}{l}\text { No. of } \\
\text { embryos } \\
\text { frozen }\end{array}$ & $\begin{array}{l}\text { No. of } \\
\text { embryos } \\
\text { recovered }\end{array}$ & $\begin{array}{l}\text { No. of } \\
\text { morphologically } \\
\text { normal embryos } \\
\text { after removal of } \\
\text { cryoprotectant }{ }^{\dagger} \\
\qquad \%) \ddagger\end{array}$ & $\begin{array}{l}\text { No. of embryos } \\
\text { developed to } \\
\text { blastocysts } \\
\text { after } 24 \mathrm{~h} \text { in } \\
\text { culture }(\%) \ddagger\end{array}$ \\
\hline \multirow[t]{2}{*}{ Slow $\S$} & 25 & $\begin{array}{l}\text { DMSO } \\
\text { Ethylene glycol } \\
\text { Glycerol } \\
\text { Erythritol }\end{array}$ & $\begin{array}{l}52 \\
53 \\
53 \\
48\end{array}$ & $\begin{array}{l}46 \\
46 \\
49 \\
44\end{array}$ & $\begin{array}{c}32(70) \\
28(61) \\
42(86) \\
0(0)\end{array}$ & $\begin{array}{c}27(59)^{\mathrm{b}} \\
23(50)^{\mathrm{b}} \\
35(71)^{\mathrm{b}} \\
0(0)\end{array}$ \\
\hline & 360 & $\begin{array}{l}\text { DMSO } \\
\text { Ethylene glycol } \\
\text { Glycerol } \\
\text { Erythritol }\end{array}$ & $\begin{array}{l}42 \\
53 \\
53 \\
54\end{array}$ & $\begin{array}{l}40 \\
53 \\
51 \\
47\end{array}$ & $\begin{array}{l}29(73) \\
32(60) \\
34(67) \\
28(60)\end{array}$ & $\begin{array}{l}28(70)^{\mathfrak{c}} \\
34(64)^{\mathrm{c}} \\
33(65)^{\mathrm{a}} \\
17(36)^{\mathrm{c}}\end{array}$ \\
\hline Rapid & 360 & $\begin{array}{l}\text { DMSO } \\
\text { Ethylene glycol } \\
\text { Glycerol } \\
\text { Erythritol }\end{array}$ & $\begin{array}{l}55 \\
54 \\
55 \\
52\end{array}$ & $\begin{array}{l}52 \\
51 \\
44 \\
42\end{array}$ & $\begin{array}{r}18(35) \\
8(16) \\
24(55) \\
33(79)\end{array}$ & $\begin{array}{l}16(31) \\
10(20) \\
17(39) \\
22(52)^{c}\end{array}$ \\
\hline
\end{tabular}

Statistical comparisons ( $\chi^{2}$ test) were made among slow-slow, slow-rapid and rapid-rapid procedures of freezethawing in each cryoprotectant: values indicated by superscripts are significantly higher: ${ }^{\mathrm{a}} P<0.05 ;{ }^{\mathrm{b}} P<0.01 ;^{\mathrm{c}} \boldsymbol{P}<$ 0.001 .

$* 1.5 \mathrm{M}$ for slow freezing and $2.0 \mathrm{M}$ for rapid freezing.

$\dagger$ Embryos were examined 1-2 $\mathrm{h}$ after start of culture.

$¥$ Percentage of the number of embryos recovered.

$\S$ For details of freezing rates, see text. 
Table 2. Offspring developed from rat morulae after freeze-thawing in the presence of various cryoprotectants and transfer to pseudopregnant recipients

\begin{tabular}{lccccccc}
\hline Cryoprotectant* & $\begin{array}{c}\text { Freezing } \\
\text { rates }{ }^{\dagger}\end{array}$ & $\begin{array}{c}\text { Thawing } \\
\text { rates } \\
\left({ }^{\circ} \mathrm{C} / \mathrm{min}\right)\end{array}$ & $\begin{array}{c}\text { Duration } \\
\text { of } \\
\text { storage } \\
\text { (days) }\end{array}$ & $\begin{array}{c}\text { No. of } \\
\text { embryos } \\
\text { transferred }\end{array}$ & $\begin{array}{c}\text { Total } \\
(\%)\end{array}$ & Male & Female \\
\hline DMSO & Rapid & 360 & 610 & 13 & $4(31)$ & 1 & 3 \\
Ethylene glycol & Slow & 25 & 626 & 12 & $4(33)$ & 3 & 1 \\
& & 360 & 108 & 7 & $0(0)$ & 0 & 0 \\
Glycerol & Slow & 25 & 86 & 14 & $7(50)$ & 2 & 2 \\
Erythritol & & 360 & 123 & 9 & $3(33)$ & 3 & 2 \\
& Rapid & 360 & 93 & 13 & $2(15)$ & 2 & 0 \\
& & & 93 & 11 & $1(9)$ & 0 & 1 \\
\hline
\end{tabular}

$* 1.5 \mathrm{M}$ for slow freezing and $2.0 \mathrm{M}$ for rapid freezing.

$\dagger$ For details, see text.

\section{Discussion}

From the results of the present study it is clear that the 4 cryoprotectants examined are effective for the freeze-preservation of rat morulae, but the survival of the embryos is affected by procedures for freezing and thawing in the various cryoprotectants. This is in agreement with our previous results for mouse embryos (Kasai et al., 1981).

Rat embryos have been successfully frozen in the presence of DMSO (Whittingham, 1975), ethylene glycol (Miyamoto \& Ishibashi, 1977) and erythritol (Fujii, Utsumi \& Yuhara, 1981). The present results showed that glycerol is also a very effective cryoprotectant for rat morulae, which contrasts with those obtained by Utsumi, Okimasu \& Yuhara (1976) for rat blastocysts.

As compared with survival rates reported previously for rat 2-8-cell embryos (Whittingham, 1975; Miyamoto \& Ishibashi, 1977) and blastocysts (Utsumi et al., 1976), higher proportions of morulae developed in culture after freeze-thawing with DMSO (70\%), ethylene glycol (64\%) and glycerol $(71 \%)$ in the present study. It seems that morulae develop more easily than do 2-8-cell embryos and blastocysts in vitro and/or may have higher freezability. In addition, the different procedures for removing cryoprotectants might improve the viability of the embryos.

When DMSO was used as a cryoprotectant, a three-step procedure for rapid freezing of mouse embryos (Kasai et al., 1980) was not adequate for rat morulae for which higher survival rates were obtained with slow than with rapid freezing in the present study (Table 1). On the other hand, with erythritol, the rapid freeze-thawing procedure was most useful both of rat (present study) and mouse (Kasai et al., 1981) morulae. However, it may be important to determine the optimal concentration of erythritol in further experiments, because it has been reported that the most effective concentration of erythritol in the freezing of mouse embryos is $0.6 \mathrm{M}$ (Miyamoto \& Ishibashi, 1981), and 10\% (0.82 M) erythritol is used in rapid freezing of rat embryos (Fujii et al., 1981).

Normal fetuses have been obtained from rat embryos frozen-thawed slowly with DMSO (Whittingham, 1975; Utsumi \& Yuhara, 1978). However, there have been very few reports on the development of frozen-thawed rat embryos into live young. Our results on embryo transfer show that rat morulae frozen-thawed with all the cryoprotectants used are capable of developing into live young when transferred to pseudopregnant animals. Since many genetic variants exist in the rat, it would be possible to re-establish breeding stocks from rat embryos stored at $-196^{\circ} \mathrm{C}$. 


\section{References}

Fujii, Y., Utsumi, K. \& Yuhara, M. (1981) A simplified rapid freezing of rat embryos by liquid nitrogen gas. Sci. Rep. Fac. Agric. Okayama Univ. 57, 25-33.

Kasai, M., Niwa, K. \& Iritani, A. (1980) Survival of mouse embryos frozen and thawed rapidly. $J$. Reprod. Fert. 59, 51-56.

Kasai, M., Niwa, K. \& Iritani, A. (1981) Effects of various cryoprotective agents on the survival of unfrozen and frozen mouse embryos. J. Reprod. Fert. 63, $175-180$.

Miyamoto, H. \& Ishibashi, T. (1977) Survival of frozen-thawed mouse and rat embryos in the presence of ethylene glycol. J. Reprod. Fert. 50, 373-375.

Miyamoto, H. \& Ishibashi, T. (1981) Survival of mouse embryos after freezing and thawing in the presence of erythritol. J. exp. Zool. 216, 337-340.
Toyoda, Y. \& Chang, M.C. (1974) Fertilization of rat eggs in vitro by epididymal spermatozoa and the development of eggs following transfer. J. Reprod. Fert. 36, 9-22.

Utsumi, K. \& Yuhara, M. (1978) Viability of frozen 2-cell eggs and blasocysts in rat. Cryobiology 15, 689, Abstr.

Utsumi, K., Okimasu, E. \& Yuhara, M. (1976) Survival of frozen rat embryos: ice formation on rat blastocyst during freezing process. Sci. Rep. Fac. Agric., Okayama Univ. 47, 59-66.

Whittingham, D.G. (1971) Survival of mouse embryos after freezing and thawing. Nature, Lond. 233, 125-126.

Whittingham, D.G. (1975) Survival of rat embryos after freezing and thawing. J. Reprod. Fert. 43, 575-578.

Received 3 March 1982 